\title{
Effect of Lamination on Shale Reservoir Properties: Case Study of the Montney Formation, Canada
}

\author{
Juhwan Woo, ${ }^{1}$ Hyun Suk Lee $\mathbb{D}^{2},{ }^{2}$ Carl Ozyer $\mathbb{D}^{3},{ }^{3}$ and Chul Woo Rhee $\mathbb{D}^{1}$ \\ ${ }^{1}$ Department of Earth and Environmental Sciences, Chungbuk National University, Cheongju 28644, Republic of Korea \\ ${ }^{2}$ Petroleum and Marine Research Division, Korea Institute of Geoscience and Mineral Resources, Daejeon 34132, Republic of Korea \\ ${ }^{3}$ Geological Survey of Canada, Calgary, Alberta, Canada
}

Correspondence should be addressed to Chul Woo Rhee; gloryees@chungbuk.ac.kr

Received 30 June 2020; Revised 17 December 2020; Accepted 6 January 2021; Published 10 February 2021

Academic Editor: Keni Zhang

Copyright $\odot 2021$ Juhwan Woo et al. This is an open access article distributed under the Creative Commons Attribution License, which permits unrestricted use, distribution, and reproduction in any medium, provided the original work is properly cited.

The presence of lamination on sedimentary rocks is a distinct characteristic, particularly in shales. They are distinct due to the contrast between successive layers with regard to grain size, composition, color, and sedimentary structures, such as graded beds. Typically, the degree of lamination is controlled by the sedimentation rate and flow regime. Herein, we developed a mudstone classification scheme in terms of lamination because lamination-based shale facies are related to differing features in mineral composition, porosity, and Young's modulus. This study also attempts to verify whether wireline log patterns are relevant to shale lithofacies. The relationship between the porosity and lamination of the Montney Formation can be used to estimate reservoir properties. Our results show that an increased silt lamina in mudstone leads to an increase in the quartz and calcite contents and a decrease in the clay content, which increases the porosity, permeability, and Young's modulus. However, reservoir quality is not solely dependent on lamination because of the complex interaction between components. The degree of lamination affected the neutron, density, and sonic log responses. Furthermore, the presence of lamination tends to decrease the neutron percentage, with similar trends in density and sonic log box plots in the study area. When the percentage of clay or cement material decreases, the neutron and density log responses diminish. Meanwhile, when the rock texture variation increases with an increase in the degree of lamination, the sonic log response decreases.

\section{Introduction}

The layering or stratification of sedimentary rocks reflects different depositional processes and environmental settings [1-4]. Shale-dominated succession commonly contains laminae that exhibit a thickness ranging from micrometer to millimeter, while demonstrating different styles such as even, discontinuous, wavy, and lenticular.

Laminated sediments reflect the compositional and textural variations due to fluctuations in sediment type and transport, water chemistry, and biogenic activity; further, they reveal the environmental setting that will preserve the laminated fabric $[3,5,6]$. Well-laminated black shales are formed by either turbidity currents, contourites, or nepheloid flows $[7,8]$. They represent either discontinuous sediment accumulation by lateral transport in bed load, or dense suspension [9] with background suspension settling, variations in sediment input, plankton productivity fluctuation, and diagenesis $[10,11]$. O'Brien $[12,13]$ suggested three lamination types of different origins: (1) fine lamination resulting from suspension settling, (2) thick lamination of the bottom-flowing current deposition, and (3) wavy lamination formed by benthic microbial mats. Each lamination can be indicative of different depositional settings and diagenetic processes. Mineral compositions are critical components for classifying shale lamination $[14,15]$; therefore, we classify the lithofacies based on the lamination pattern and their background deposits.

Previous studies have revealed that the degree of lamination is indicative of the shale geomechanical characteristics and the influence on rock failure [16-18]. The laminae show vertical changes in texture, composition, and planes exhibiting weakness that influence the efficiency of hydraulic fracturing. The tensile strength perpendicular to lamination is 

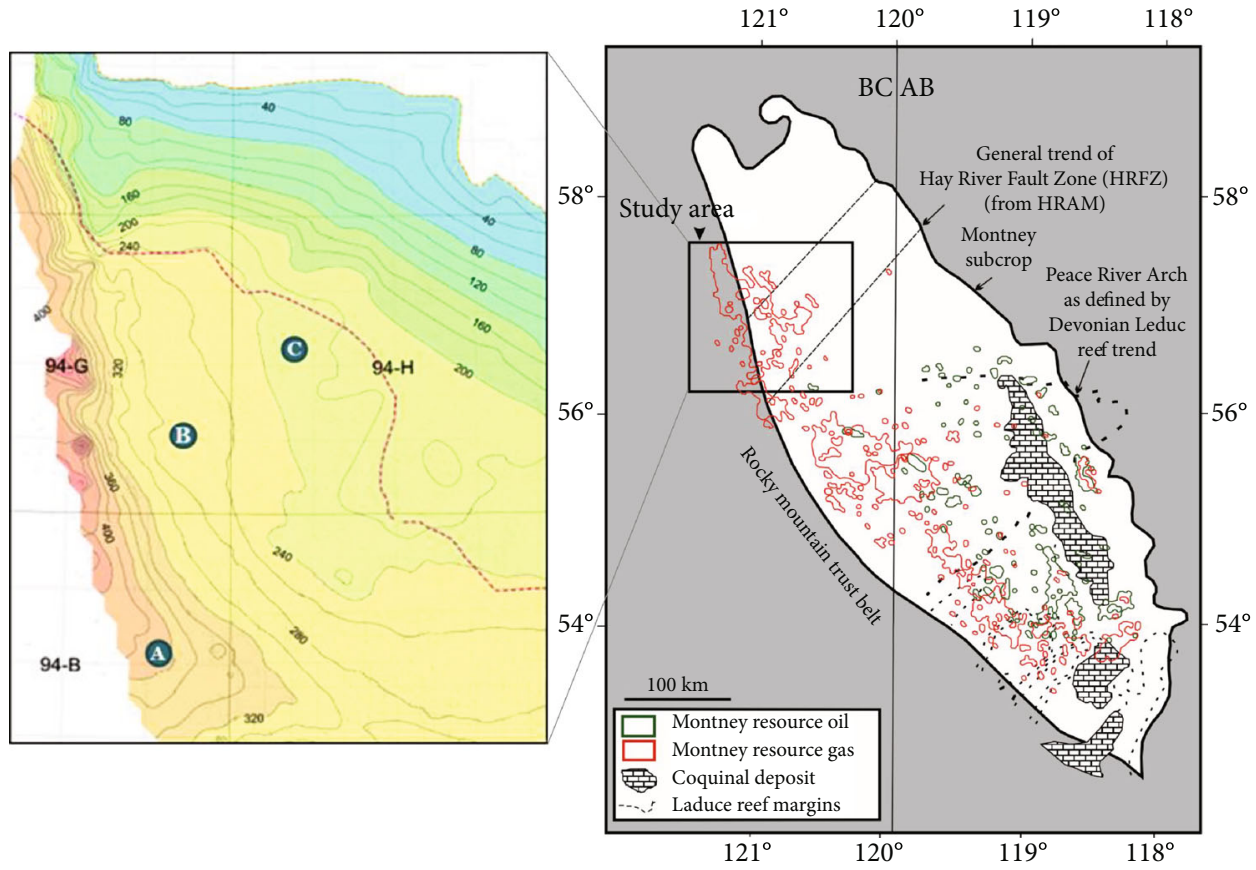

Figure 1: Location of the Montney Formation in Alberta and British Columbia where structural elements and the coquina facies trends are NW to SE. Inset isopach map of the study area with well locations A-C.

higher than the tensile strength parallel to lamination $[16,19$, 20]. Thin beds/laminae show a better hydraulic fracture effect than homogeneous shales [21].

Shale lamination reflects temporal variations in sediment supply and flow velocity and may include ripple migration [22] or alignment of platy minerals. Therefore, lamination can be a key feature of shales in terms of porosity, permeability, and shale brittleness. This study attempts to reveal the petrophysical implications of shale lamination with an emphasis on the relationship between lithofacies and sedimentary processes and their reservoir characteristics. This work is partly a circumstantial verification of the usefulness of existing mudrock classification schemes that do not consider shale heterogeneity derived from lamination.

\section{Geological Setting}

The Lower Triassic Montney Formation was deposited in the Western Canada Sedimentary Basin in northeast (NE) British Columbia and northwestern (NW) Alberta, covering approximately $130,000 \mathrm{~km}^{2}$ [23-25]. It is exposed within the deformed belts of the rocky mountain foothill to the west and its subcrops to the east where it was eroded during the Late Jurassic and Early Cretaceous periods [26] (Figure 1).

The Montney Formation is unconformably underlain by the upper Permian Belloy Formation and conformably overlain by the Middle Triassic Doig Formation (Figure 2) $[24,25]$. The Montney Formation is subdivided into the lower, middle, and upper Montney sequences, which correspond to the Griesbachian-Dienerian Induan Age, the Smithian, and the Spathian substage of the Olenekian Age, respectively [27-30].

\begin{tabular}{|c|c|c|c|c|}
\hline \multicolumn{4}{|c|}{ Stages, substages } & $\begin{array}{c}\text { Third-order } \\
\text { sequences } \\
\text { (Crombez et al., 2016) }\end{array}$ \\
\hline \multirow{5}{*}{ 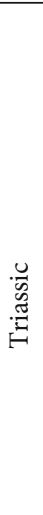 } & $\frac{0}{\tilde{z}}$ & & $\begin{array}{c}\text { Anisian } \\
\text { 'Anisian wedge' }\end{array}$ & Sequence 4 \\
\hline & \multirow{4}{*}{$\begin{array}{l}\text { : } \\
\text { 离 }\end{array}$} & \multirow[t]{2}{*}{ 糟 } & $\begin{array}{c} \\
247.1 \pm 0.2 \mathrm{Ma} \\
\text { Spathian }\end{array}$ & $\begin{array}{c}\text { Sequence } 3 \\
\text { (M3) }\end{array}$ \\
\hline & & & $\begin{array}{c}\mathbf{4} \\
248.6 \mathrm{Ma} \\
\text { Smithian } \\
\approx 250 \mathrm{Ma} \\
\downarrow\end{array}$ & $\begin{array}{l}\text { Sequence } 2 \\
\text { (M2) }\end{array}$ \\
\hline & & \multirow{2}{*}{$\mid$} & Dienerian & \multirow{2}{*}{$\begin{array}{l}\text { Sequence } 1 \\
\text { (M1) }\end{array}$} \\
\hline & & & Griesbachian & \\
\hline 荀 & 苟 & & $\begin{array}{c}\mathbf{4} \\
251.9 \pm 0.07 \mathrm{Ma} \\
\text { Changhsing }\end{array}$ & \\
\hline
\end{tabular}

Figure 2: Stratigraphic chart of the Montney Formation, which has been modified to the third-order sequences from the study by Crombez et al. (2016). The dashed grey line represents angular unconformity.

The Montney Formation comprises different lithofacies of siliciclastic, bioclastic, dolomitic, and phosphatic sediments that have been primarily deposited within the shallow marine (shoreface through offshore) environment on a broad westerly dipping ramp or inner shelf $[28,30,31]$. Subaqueous deltaic and tide-influenced deposits are dominant in the 

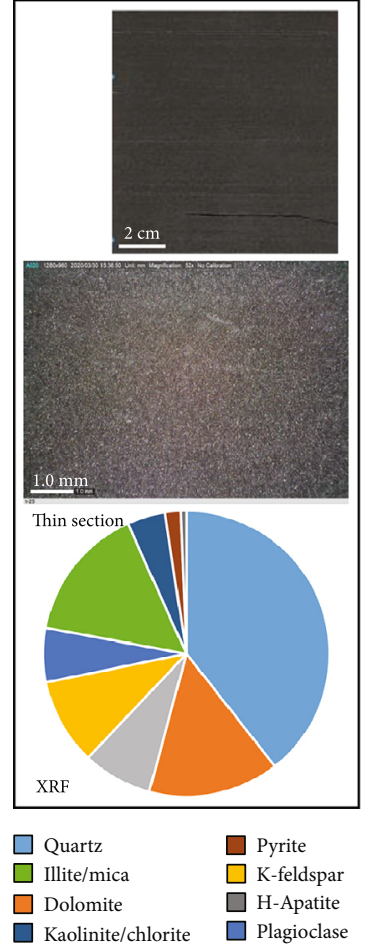

$\square$ Kaolinit

(a)

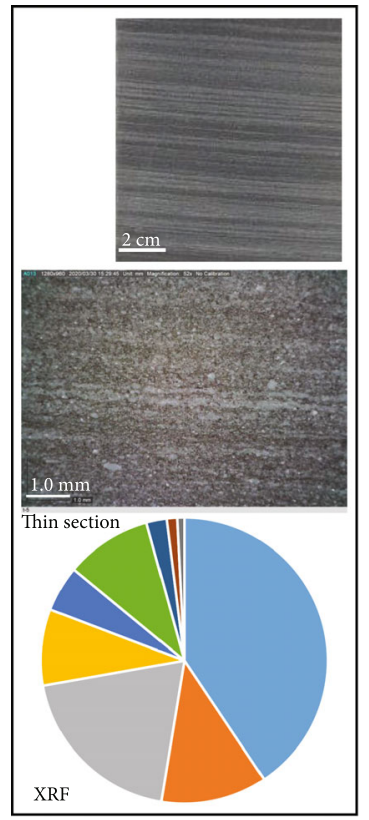

$\square$ Quartz

$\square$ Illite/mica

$\square$ Dolomite

$\square$ Calcite
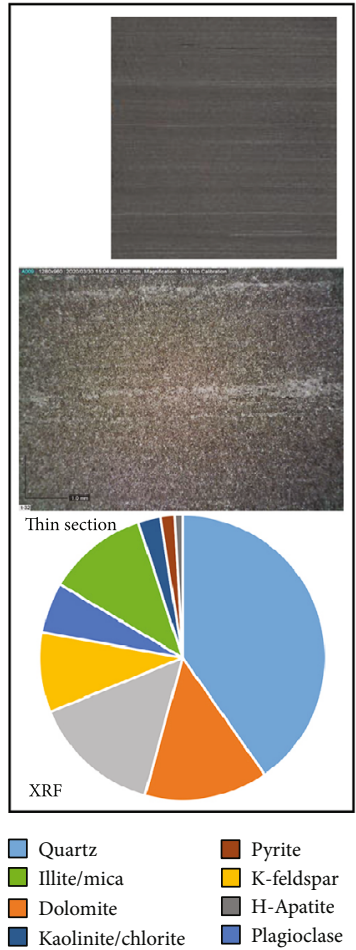

$\square$ Kaolinite/chlorite

$\square$ Calcite

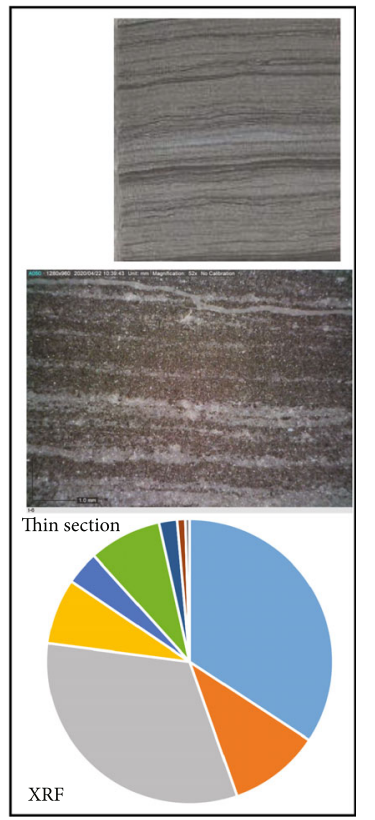

$\square$ Quartz

$\square$ Illite/mica

$\square$ Dolomite

$\square$ Kaolinite/chlorite $\square$ Plagioclase

$\square$ Calcite

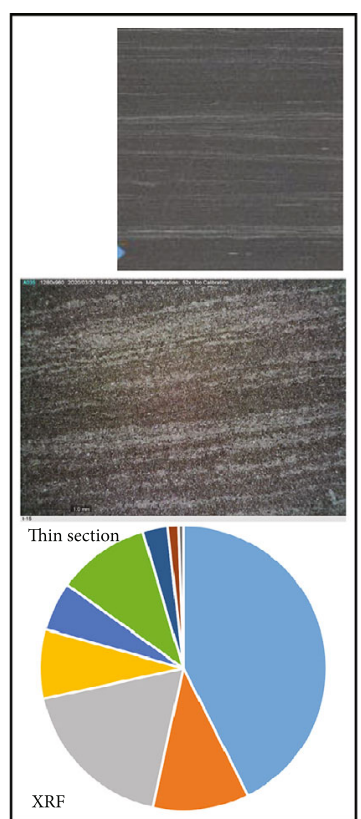

$\square$ Quartz

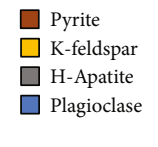

(b)

\section{$\square$ Quartz \\ $\square$ Illite/mica \\ $\square$ Dolomite}

$\square$ Kaolinite/chlorite

$\square$ Calcite

(c)

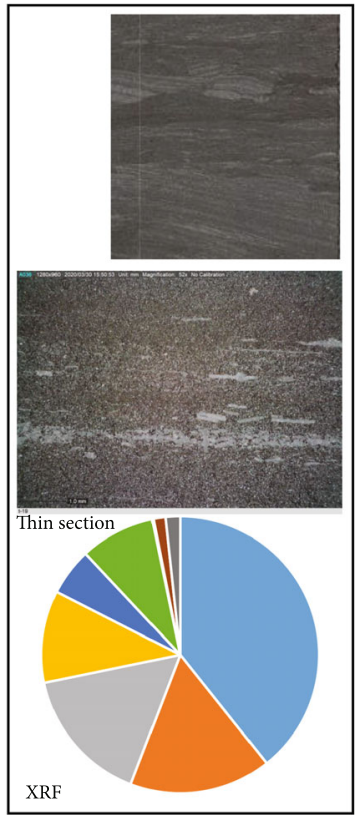

$\square$ Illite/mica

$\square$ Dolomite

$\square$ Kaolinite/chlorite

$\square$ Calcite

(f)

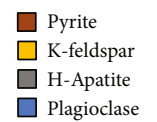

$\square$ H-Apatite
$\square$ Plagioclase

(g)
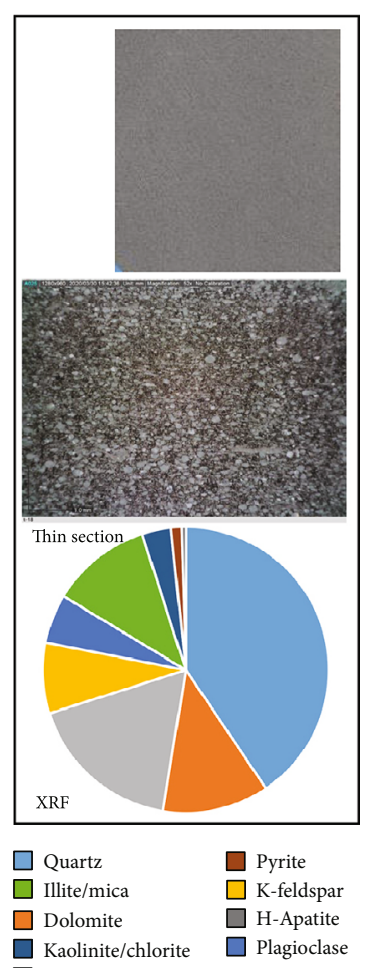

$\square$ Calcite

(d)
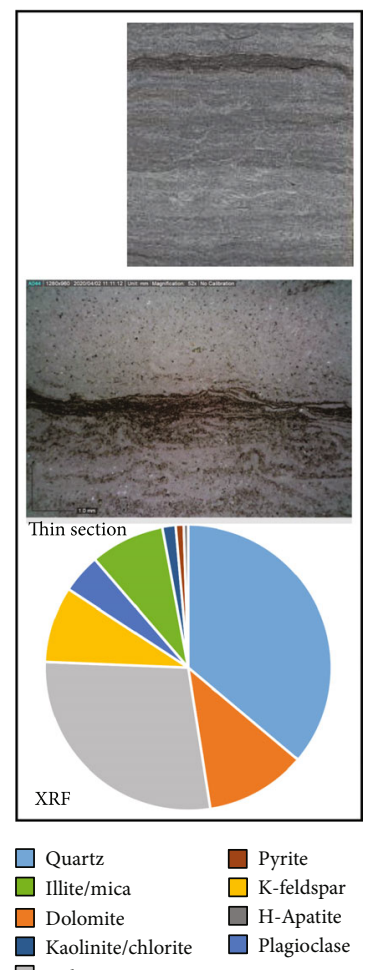

$\square$ Calcite

(h)

FIGURE 3: Photographs of lithofacies taken from the core, thin-section photographs, and XRF results associated with (a) homogeneous mudstone (LF1), (b) very thin laminated mudstone (LF2), (c) thin evenly parallel laminated mudstone (LF3), (d) massive siltstone with indistinctive lamination (LF4), (e) thin evenly parallel laminated siltstone (LF5), (f) thin to thick and wavy laminated siltstone (LF6), (g) bioturbated siltstone (LF7), and (h) dolomitic siltstone (LF8). 
TABLE 1: X-ray fluorescence (XRF) analytical results mineral composition percentage of the Montney Formation in well b-066-D/094-H-12. Data were sourced from BCOGC.

\begin{tabular}{lccccccccc}
\hline & Quartz & Dolomite & Calcite & K-feldspar & Plagioclase & Illite/mica & Kaol/chlor & Pyrite & H-apatite \\
\hline LF1 & 38.8 & 14.5 & 7.7 & 9.6 & 6.0 & 15.1 & 4.2 & 1.7 & 0.7 \\
LF2 & 39.6 & 13.8 & 14.3 & 8.9 & 5.6 & 11.2 & 2.5 & 1.5 & 0.9 \\
LF3 & 41.8 & 10.7 & 17.8 & 7.7 & 5.5 & 10.3 & 2.8 & 1.2 \\
LF4 & 39.9 & 11.9 & 17.2 & 7.9 & 5.5 & 11.2 & 3.2 & 1.2 \\
LF5 & 40.0 & 11.8 & 19.3 & 8.5 & 5.1 & 9.6 & 2.2 & 0.6 \\
LF6 & 33.8 & 10.2 & 32.0 & 7.4 & 3.8 & 8.1 & 2.5 & 0.8 \\
LF7 & 38.7 & 16.2 & 15.7 & 10.6 & 5.4 & 8.6 & 0.2 & 1.2 & 0.9 \\
LF8 & 35.6 & 11.2 & 27.7 & 8.5 & 4.4 & 8.3 & 1.5 & 0.9 \\
\hline
\end{tabular}

eastern part, and deep-water submarine fans and related turbidite systems have developed in the western part $[28,32]$.

The isopach map of the Montney Formation shows its depositional slope toward the northeast along the paleolow (Figure 1). It is thickest in the center of the Peace River Embayment but gradually thins eastwards, where the outcrop limit is truncated by the Jurassic strata [26, 28, 33]. The paleostructure influenced the depositional trends and facies distribution/development of three distinctive stratigraphic units $[28,34]$.

\section{Data and Methods}

We sedimentologically described three cores (overall $577 \mathrm{~m}$ ) in this study, with emphasis on the texture, sedimentary structure, and nature of the bedding contacts. We employed X-ray fluorescence spectroscopy (XRF) on 902 samples and $\mathrm{X}$-Ray Diffraction (XRD) analysis on 38 samples to identify the mineral composition of b-066-D/094-H-12 (well C). The major element compositions of the XRF data were converted to their respective mineralogy through normative calculations. In addition, six thin sections were analyzed to identify and characterize texture, sediment composition, and cementation.

The porosity and air permeability (Kmax and K90) of b066-D/094-H-12 samples (well C) were assessed by CoreLab. Porosity was measured using Boyle's law, and permeability was obtained using steady-state measurements performed at a confining pressure of $3.45 \mathrm{MPa}$ (500 psi). Thin-section images were used to verify the grain and porosity shapes. Porosity identification in thin sections was enhanced by pink epoxy infilling of the intergranular spaces.

Derived porosity was calculated from neutron and density measurements. Sonic and density logs were used to calculate geomechanical properties such as Young's modulus and Poisson's ratio. Total organic carbon (TOC) content values were calculated from the $\Delta \log R$ analysis models. Detrital framework components, total clay and cement contents (mostly carbonates), geomechanical properties, derived porosity, and TOC were used to define reservoir quality (RQ).

\section{Results}

Descriptions of the three cores on the 1:20 scale cover the entire stratigraphic section of the Montney Formation. Based on sedimentological descriptions, the following eight lithofacies are classified in the study area: homogeneous mudstone (LF1), very thin laminated mudstone (LF2), thin evenly parallel laminated mudstone (LF3), massive siltstone with indistinctive lamination (LF4), thin evenly parallel laminated siltstone (LF5), thin to thick and wavy laminated siltstone (LF6), bioturbated siltstone (LF7), and calcareous dolosiltstone (LF8) (Figure 3). Following the suggestions of O'Brien (1996), we also classified the degree of lamination development as finely laminated, thickly laminated, and wavy lamination. We have identified the following three main types of lamination: (1) very thin $(<0.1 \mathrm{~mm}),(2)$ thin $(<0.3 \mathrm{~mm})$, and (3) thin to thick $(0.3 \sim 1.0 \mathrm{~mm})$.

Based on the XRD analysis, augmentations in lamination tend to occur with an increase in the quartz and calcite contents; however, the degree of lamination decreases in minerals such as dolomite, $\mathrm{K}$-feldspar, and clay minerals. These differing lamination lithofacies are consistent with the XRF analysis results, implying that the mineralogical composition of laminae varies with the type of lithofacies. The laminae are mainly composed of silt, which may increase quartz contents.

\subsection{Lithofacies Description}

(1) Homogeneous mudstone (LF1): this lithofacies is characterized by an overall absence of primary structures, except for the occasional micro cross-ripple lamination in some units (Figure 3(a)). It appears massive, with an overall absence of biogenic structures and soft-sediment deformation. Thin sections of this lithofacies show no distinct porosity, due to higher clay contents. Mineralogically, it is predominantly comprised of quartz (avg: $38.8 \%$, detrital and authigenic, and minor chert) and clays (avg: 19.4\%), variable amounts of plagioclase (avg: 6\%), Kfeldspar (avg: 9.6\%), dolomite (avg: 14.5\%), calcite (avg: $7.7 \%$ ), pyrite (avg: $1.7 \%$ ), and organic matter (less than 1\%) (Table 1)

(2) Very thin laminated mudstone (LF2): this lithofacies is characterized by very thin parallel laminated dark to light grey mudstone. Overall, it comprises very thin light grey silt laminae that are occasionally continuous, with some lamination thinner than $0.1 \mathrm{~mm}$ that comprise indistinctive boundaries 


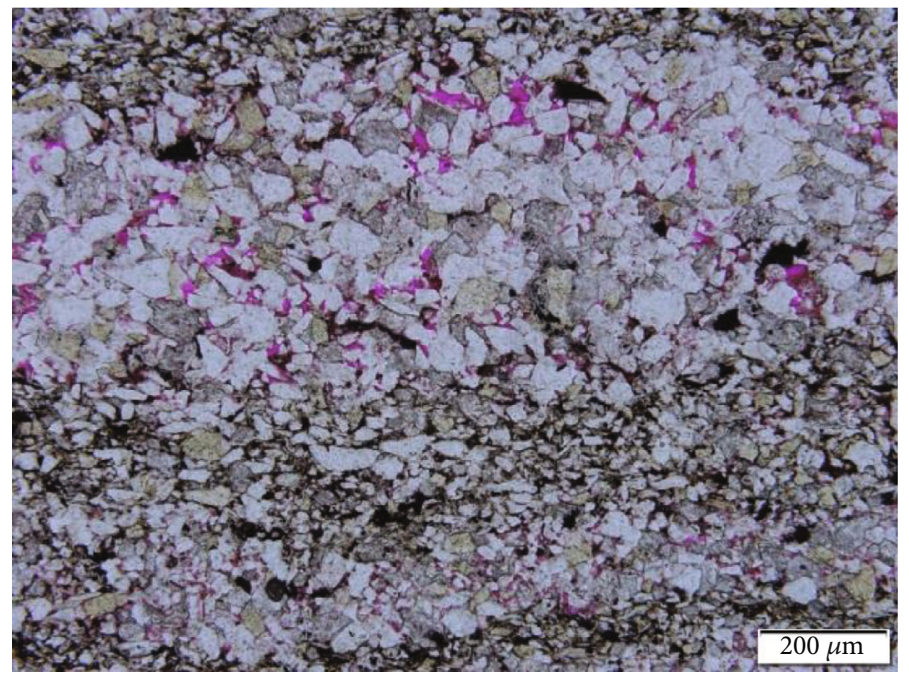

(a)

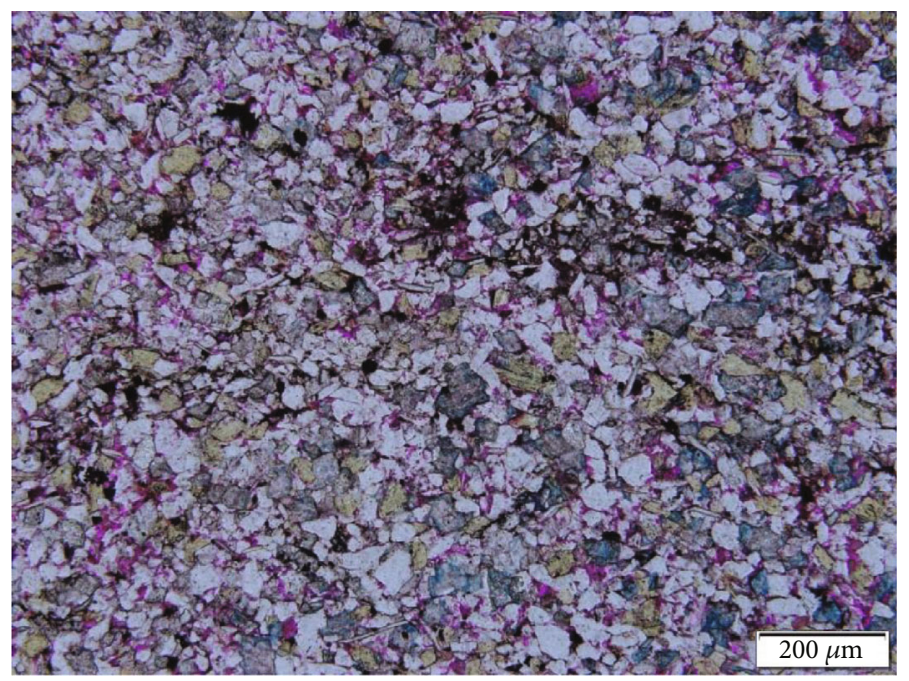

(b)

FIgURE 4: (a) Photomicrograph of LF3 showing thin laminae with intergranular porosity (pink epoxy) and small pore in the fine-grained opaque-rich laminae and (b) photomicrograph LF4 showing intergranular pore with pink epoxy.

(Figure 3(b)). A typical thin section image of this lithofacies shows a finely laminated, mixed siliceous siltstone with high clay content. Mineralogically, this lithofacies consists predominantly of quartz (average: $39.6 \%$; detrital and authigenic as well as minor chert), clays (avg: $13.7 \%$ ), variable amounts of plagioclase (avg: 5.6\%), K-feldspar (avg: 8.9\%), dolomite (avg: $13.8 \%$ ), calcite (avg: $14.3 \%$ ), pyrite (avg: $1.5 \%$ ), and organic matter (less than 1\%) (Table 1)

(3) Thin evenly parallel laminated mudstone (LF3): this mudstone comprises interlaminated light grey, fine to medium-grained siltstone. There is no distinctive contrast between the fine and coarse siltstone laminae/lenticular structures. The fine-silt laminae are either horizontal or very low angle cross-laminae. The thickness of the individual fine silt and clay laminae couplet of this lithofacies is approximately
1-1.5 mm (Figure 3(c)). Thin section petrography shows silt-sized, subangular to subrounded grains (Figure 4(a)). Mineralogically, the lithofacies consists predominantly of quartz (avg: $41.8 \%$; detrital and authigenic as well as minor chert) and clays (avg: 13.1\%), variable amounts of plagioclase (avg: 5.5\%), K-feldspar (avg: 7.7\%), dolomite (avg: 10.7\%), calcite (avg: 17.8\%), pyrite (avg: 1.2\%), and organic matter (less than 1\%) (Table 1)

(4) Massive siltstone with indistinctive lamination (LF4): this lithofacies is composed of very fine to coarsegrained siltstone. Some beds of this lithofacies show inverse grading from base to top, with medium light grey colors (Figure $3(\mathrm{~d})$ ). The thin-section micrograph shows variable, visual intergranular pores within the coarse-grained layers (Figure 4(b)). Mineralogically, the lithofacies consists of quartz 


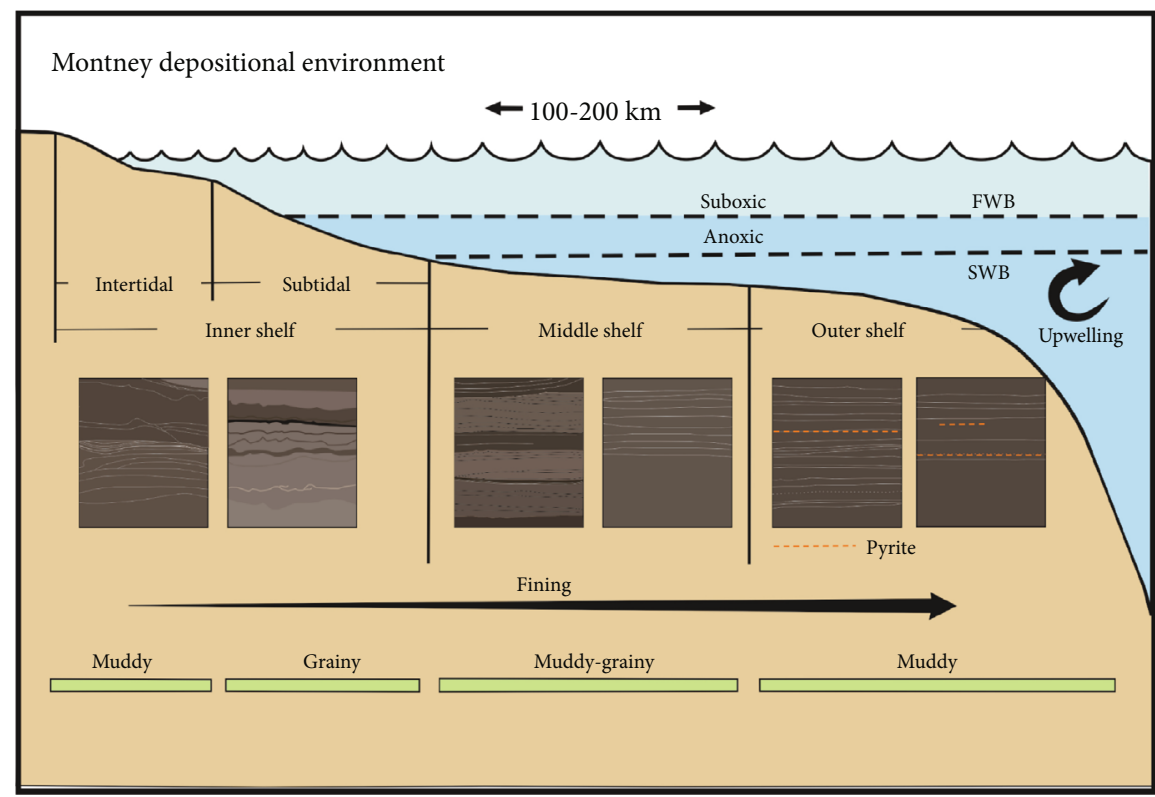

FIGURE 5: Schematic diagram of the Montney depositional environment, showing three different sedimentary structures with laminae. FWB: fair-weather wave base; SWB: storm wave base.

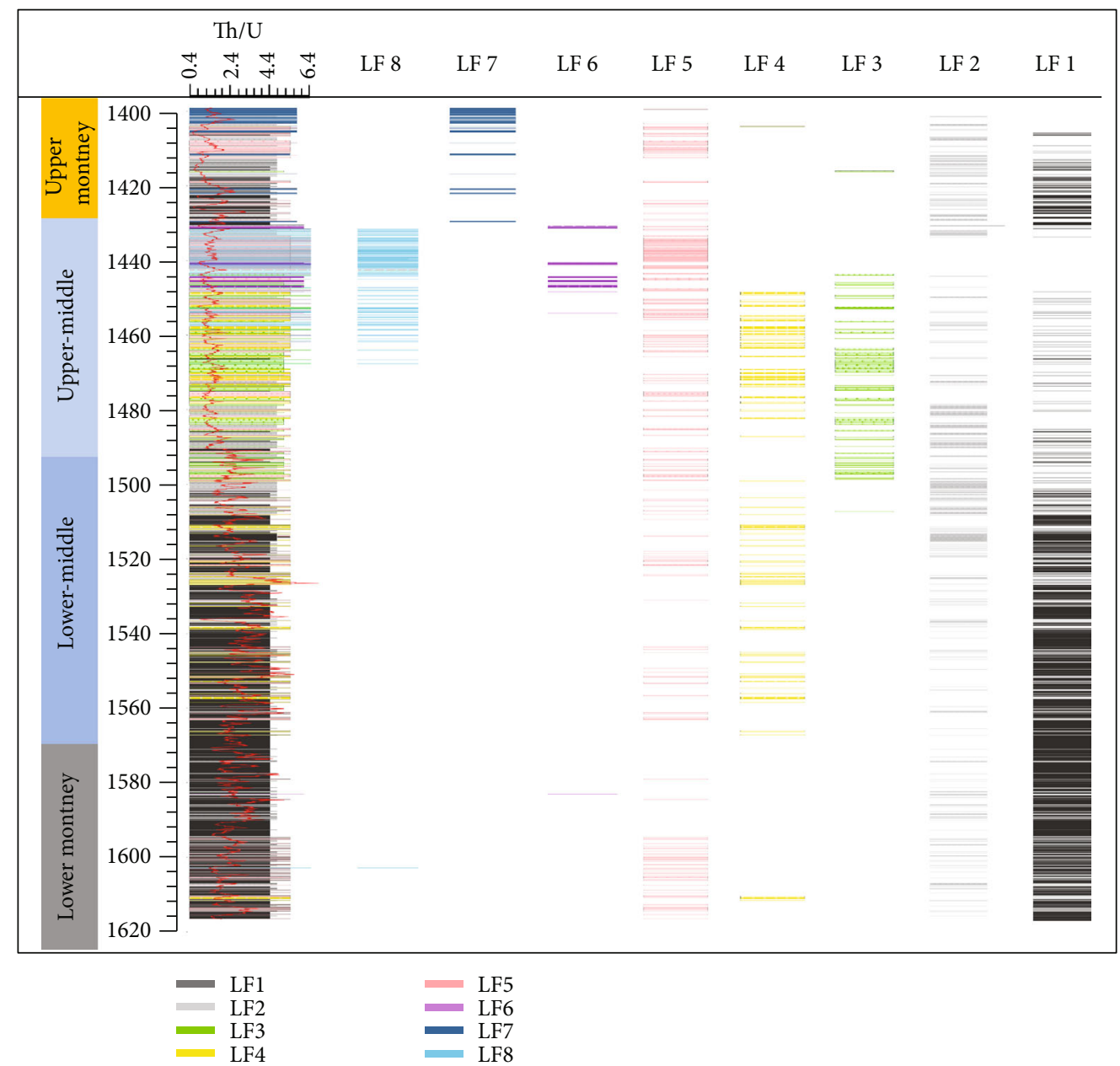

FIGURE 6: Occurrence trend of each lithofacies at well C. The first column shows digitalized lithofacies (223 m) in b-066-D/094-H-12 based on sedimentology description and spectral gamma ratios $(\mathrm{Th} / \mathrm{U})$. 
TABLE 2: Summary of the lithology, sedimentary structure, and characteristics of lithofacies.

\begin{tabular}{|c|c|c|c|c|c|c|}
\hline & Lithology/grain size & Fabric & $\begin{array}{l}\text { Sedimentary structure } \\
\text { process of deposition }\end{array}$ & $\begin{array}{l}\text { Depositional } \\
\text { environment }\end{array}$ & Porosity & RQ \\
\hline LF1 & $\begin{array}{l}\text { Homogeneous } \\
\text { mudstone }\end{array}$ & $\begin{array}{l}\text { Indistinctive } \\
\text { lamination }\end{array}$ & $\begin{array}{l}\text { Sedimentation when } \\
\text { fine-grain sediment from } \\
\text { suspension under the lower } \\
\text { density bottom currents } \\
\text { below maximum storm } \\
\text { wave base }\end{array}$ & Outer shelf & $0.4 \sim 6.3$ (Avg 3.03) & 4.8 9.0 (Avg 3.23) \\
\hline LF2 & $\begin{array}{l}\text { Very thin laminated } \\
\text { mudstone }\end{array}$ & Very thin laminae & Same above & Outer shelf & $1.1 \sim 8.9($ Avg 4.03) & 5.8 9.5 (Avg 4.34) \\
\hline LF3 & $\begin{array}{l}\text { Thin evenly parallel } \\
\text { laminated mudstone }\end{array}$ & $\begin{array}{c}\text { Thin-silt laminae, } \\
\text { low angle cross } \\
\text { laminae }\end{array}$ & $\begin{array}{l}\text { Deposition could } \\
\text { be possible from dilute } \\
\text { turbidity current }\end{array}$ & $\begin{array}{l}\text { Outer/ } \\
\text { middle shelf }\end{array}$ & 2.2 7.7 (Avg 4.77) & 6.4 9.1 (Avg 5.11) \\
\hline LF4 & $\begin{array}{l}\text { Massive siltstone with } \\
\text { indistinctive lamination }\end{array}$ & $\begin{array}{c}\text { Inverse } \\
\text { grading/indistinctive } \\
\text { lamination }\end{array}$ & $\begin{array}{l}\text { Turbidity currents } \\
\text { mechanism }\end{array}$ & Middle shelf & $\begin{array}{c}1.0 \sim 10.3(\mathrm{Avg} \\
4.64)\end{array}$ & 5.2 9.8 (Avg 4.91) \\
\hline LF5 & $\begin{array}{l}\text { Thin evenly parallel } \\
\text { laminated siltstone }\end{array}$ & $\begin{array}{l}\text { Thin clay } \\
\text { laminae/cross } \\
\text { laminae }\end{array}$ & $\begin{array}{l}\text { Diluted and transformed } \\
\text { into turbidity } \\
\text { currents mechanism }\end{array}$ & Middle shelf & 1.4 8.7 (Avg 4.96) & 6.8 9.5 (Avg 5.32) \\
\hline LF6 & $\begin{array}{l}\text { Thin to thick and wavy } \\
\text { laminated siltstone }\end{array}$ & $\begin{array}{l}\text { Thin to thick } \\
\text { laminae/wavy } \\
\text { laminae }\end{array}$ & $\begin{array}{l}\text { Cryptobioturbation } \\
\text { lower/middle shoreface }\end{array}$ & Inner shelf & $3.5 \sim 8.1$ (Avg 5.78) & 7.9 9.1 (Avg 6.15) \\
\hline LF7 & Bioturbated siltstone & $\begin{array}{l}\text { Shear/flame/ } \\
\text { loading/ripple }\end{array}$ & $\begin{array}{l}\text { Bed load transport } \\
\text { under the lower density } \\
\text { bottom currents }\end{array}$ & Inner shelf & $2.8 \sim 5.8($ Avg 4.03) & 7.6 8.6 (Avg 4.42) \\
\hline LF8 & Calcareous dolosiltstone & Wavy lamination & $\begin{array}{c}\text { Storm generated } \\
\text { currents/maximum } \\
\text { fair-weather wave base } \\
\text { and mean storm wave base }\end{array}$ & Inner shelf & 2.8 9.1 (Avg 6.15) & 7.4 9.7 (Avg 6.56) \\
\hline
\end{tabular}

(avg: 39.9\%; detrital and authigenic as well as minor chert) and clays (avg: 14.5\%), variable amounts of plagioclase (avg: 5.5\%), K-feldspar (avg: 7.9\%), dolomite (avg: 11.9\%), calcite (avg: 17.2\%), pyrite (avg: $1.2 \%$ ), and organic matter (less than $1 \%$ ) (Table 1)

(5) Thin evenly parallel laminated siltstone (LF5): this lithofacies is composed of laminated, very fine to coarse-grained siltstone. Some layers of this lithofacies exhibit a cross-lamination structure. The thin section image clearly shows fine lamination (Figure 3(e)). Mineralogically, the lithofacies consists predominantly of quartz (avg: 40\%; detrital and authigenic as well as minor chert) and clays (avg: $11.8 \%$ ), variable amounts of plagioclase (avg: 5.1\%), K-feldspar (avg: 8.5\%), dolomite (avg: 11.8\%), calcite (avg: $19.3 \%$ ), pyrite (avg: $1.2 \%$ ), and organic matter (less than 1\%) (Table 1)

(6) Thin to thick and wavy laminated siltstone (LF6): this lithofacies is characterized by lightly bioturbated, wavy, interbedded, and laminated siltstone to medium to coarse grain. The coarse-grained laminae are interbedded with fine-grained, opaque particlerich layers. The thin section image shows a finely laminated carbonate-rich siliceous siltstone (Figure 3(f)). Mineralogically, the lithofacies consists predominantly of quartz (avg: 33.8\%; detrital and authigenic) and clays (avg: 10.1\%), variable amounts of plagioclase (avg: 3.8\%), K-feldspar (avg: 7.4\%), dolomite (avg: 10.2\%), calcite (avg: 32\%), pyrite (avg: 0.9\%), and organic matter (less than 1\%) (Table 1)

(7) Bioturbated siltstone (LF7): this lithofacies is composed of interlaminated fine to coarse-grained siltstone and highly bioturbated, rippled, coarsegrain siltstone. This lithofacies is characterized by abundant asymmetric climbing ripples, with loading and flame structures (Figure 3(g)). It also comprises abundant soft-sediment deformation, dewatering structures, micro cross-ripple laminae, and highly bioturbated planar laminae; body fossils are not present. This lithofacies consists predominantly of quartz (avg: 38.7\%; detrital and authigenic) and clays (avg: $8.72 \%$ ), variable amounts of plagioclase (avg: $5.4 \%$ ), K-feldspar (avg: 10.6\%), dolomite (avg: 16.2\%), calcite (avg: $15.7 \%$ ), pyrite (avg: $1.4 \%$ ), and organic matter (less than $1 \%$ ) (Table 1)

(8) Dolomitic siltstone (LF8): this lithofacies is characterized by massive, finely crystalline carbonate deposits of a milky white color. It comprises a normally graded bioclastic packstone/grain bed with abundant small pyrite nodules (Figure $3(\mathrm{~h})$ ). The thin section image (Figure $3(\mathrm{~h})$ ) shows a crystalline 


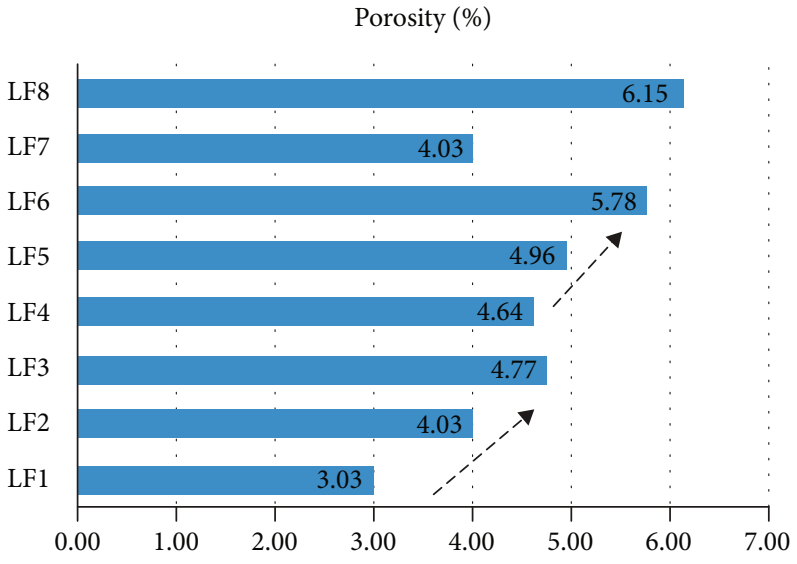

(a)

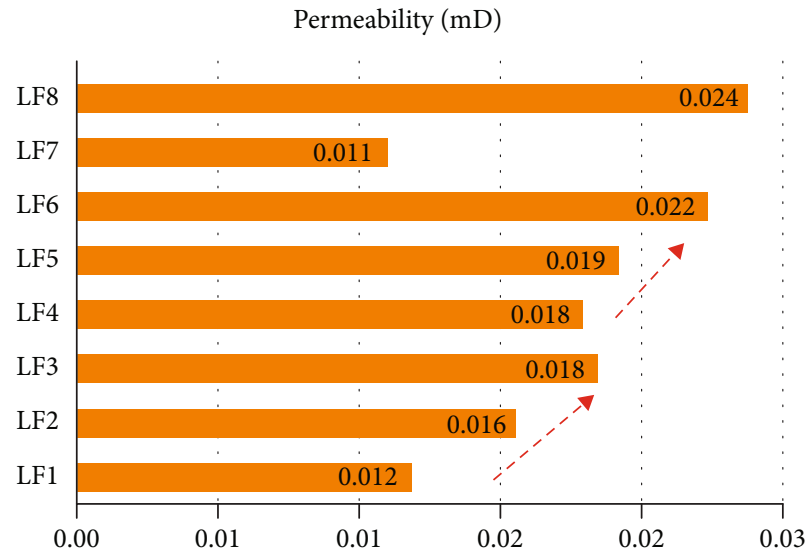

(b)

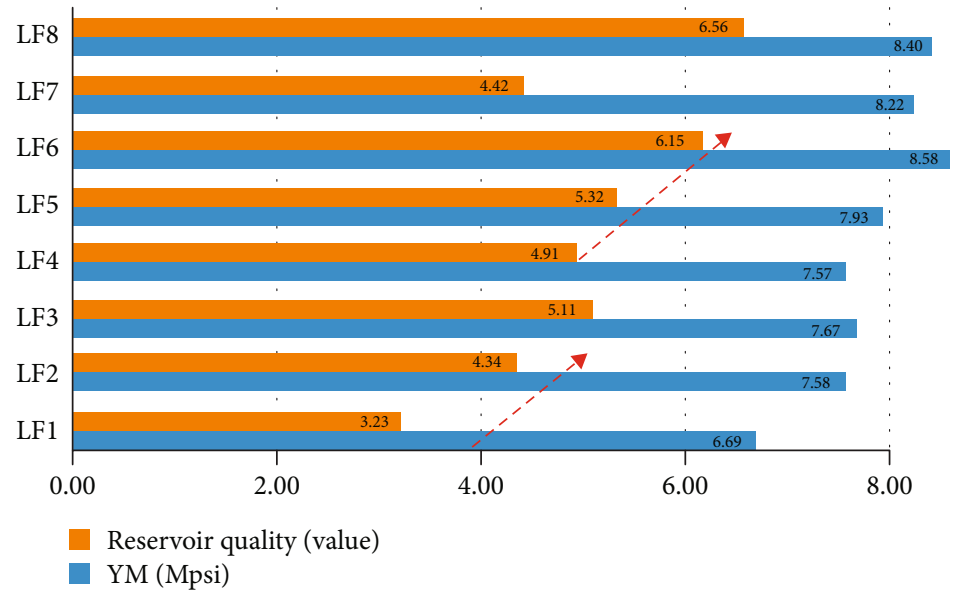

(c)

Figure 7: (a) Average porosity percentages of each lithofacies, (b) average permeability, (c) average Young's modulus (YM), and reservoir quality (RQ).

shape with small pyrite grains. The lithofacies consists predominantly of quartz (avg: $35.6 \%$; detrital and authigenic) and clays (avg: 9.7\%), variable amounts of plagioclase (avg: 4.4\%), K-feldspar (avg: $8.5 \%$ ), dolomite (avg: $11.2 \%$ ), calcite (avg: $27.7 \%$ ), pyrite (avg: $0.9 \%$ ), and organic matter (less than 1\%) (Table 1)

\section{Discussion}

5.1. Characteristics of Lamination and Their Depositional Processes. Various types of lamination in shales reflect diverse sedimentary processes $[6,13,35]$. A lamination typically results from minor fluctuations in other respects constant physical conditions of sediment supply and water movement [36]. Until the flume experiment was conducted, the lamination was largely explained in terms of alternating currents and quiet interludes. The experiment revealed that the textural lamination of silt laminae in shale develops according to the critical flow velocity for clays $(25 \mathrm{~cm} / \mathrm{sec})$ and sedimentation rate [6]. Mixed sediments of silt and clay-sized particles result in the migration of two ripples, with one formed by clay floccules and the other formed by coarse silt [22,
37]. We classify laminae of the Montney Formation based on lithology: mudstone-dominated facies as group A (LF1, LF2, and LF3), siltstone-dominated lithofacies as group B (LF4 and LF5), and others (LF6, LF7, and LF8). Group A is mainly composed of dark grey mudstone as background deposits, with light grey continuous or discontinuous silt laminae. Those lithofacies are characterized by faint lamination or alternating very thin to thin laminae of silt and mud. Most laminae are discontinuous and less than $0.3 \mathrm{~mm}$ thick. They are occasionally lens shaped and contain diagenetic features such as pyrite nodules. Lithofacies of group A may represent suspension fallout deposits. LF3 comprises thin, evenly parallel laminae with few sinusoidal micro crossripple stratifications, which may be indicative of an increase in the traction load relative to a suspended one [38].

The abundant silt grain in lithofacies of group B is characterized by graded and very fine siltstone deposits, overlying flow ripple or parallel stratification. This distinctive graded siltstone, combined with other stratification, is often reminiscent of fine-grained turbidites. Turbidity current tends to deposit clay more rapidly in the flocculated state [39]. The variation in the clay minerals comprising shales may represent clues for sediment provenance. Illite is the most 


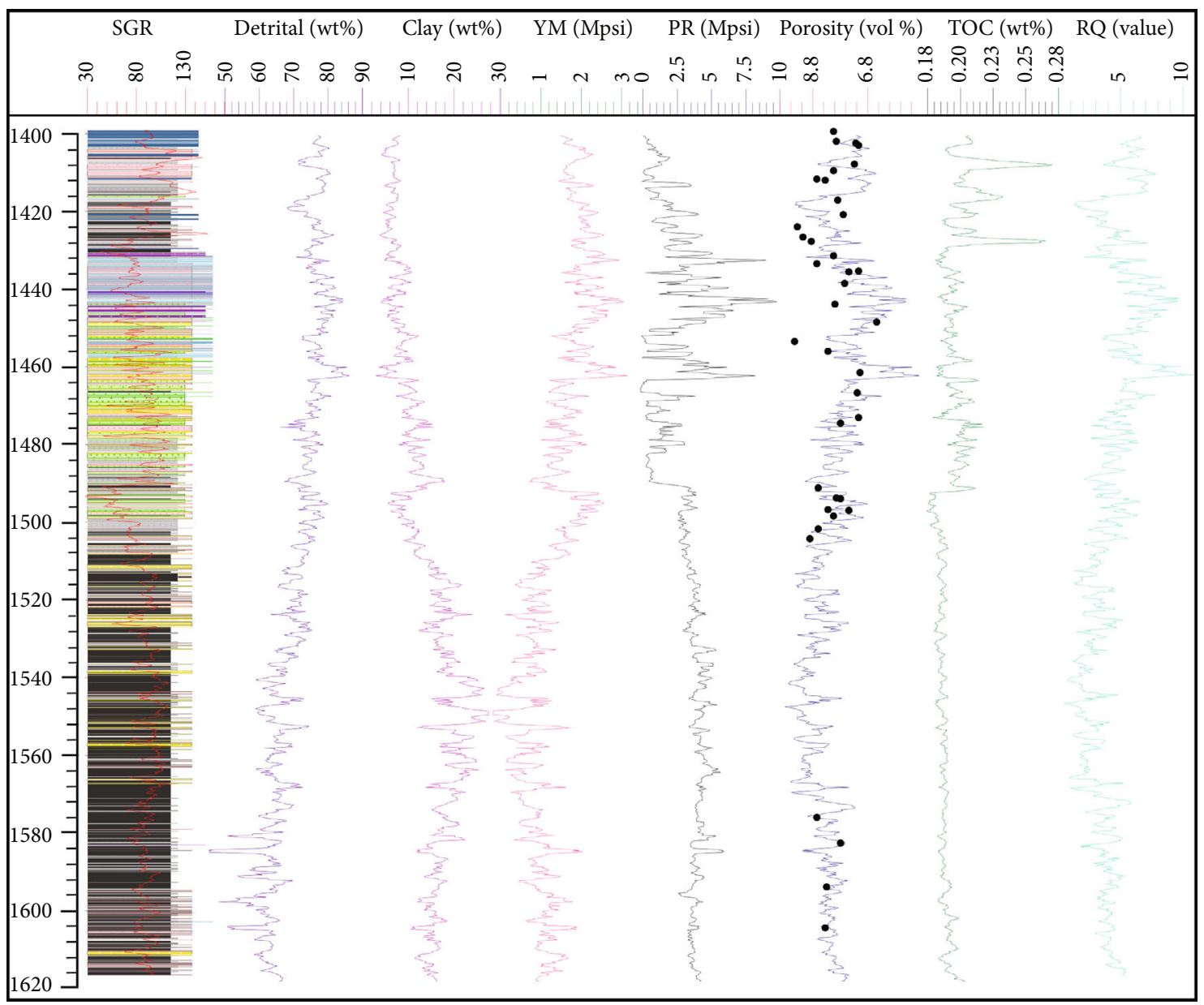

FIGURE 8: First column shows core lithofacies with spectral gamma ray (red). Major rock-forming components are compared with predicted mechanical properties, Young's Modulus (YM), Poisson's ratio (PR), calculated porosity, calculated TOC, and reservoir quality (RQ).

abundant clay mineral that derived preexisting shales such as LF1. On the other hand, LF4 exhibits high kaolinite contents, which may have been transported by turbidity; the sediments of kaolinite were fed from shallow water or continent provenance $[40,41]$ (Table 1). LF5 is characterized by cross or parallel laminae that may have formed through the bed load transport of flocculated mud by currents [22]. LF6 comprises interbedded laminated and very fine-grained sandy siltstone. It is commonly characterized by slightly wavy parallel, crossstratification, soft-sediment deformation, and cryptobioturbation. This lithofacies is interpreted as a storm-dominated, lower to middle shoreface environment. Diverse burrow traces with sediment deformation (LF7) and $5-15 \mathrm{~cm}$ thick bioclastic tempestite bed (LF8) are distinctive in the upper part of the Montney Formation.

Lamination patterns are approximately in line with previously reported depositional environments of the Montney Formation, ranging from distal offshore to outer shelf and shoreface ramp depositional settings [27, 30, 31, 42] (Figure 5).

Fine to coarse silts and alternating bioturbated siltstone represent an inner-shelf setting where the bioclastic tempestite bed occurs (Figure 5). Thin and cross laminae within siltstone background deposits suggest a middle-shelf setting.
The thinnest laminae within mudstone dominant background deposits are indicating an outer-shelf setting. The lateral distribution of alternate silt and shale lithofacies suggests that the sediment source was the primary control on lithofacies zonation. Below the storm wave base sediment, the deposited anoxic environment shows two types of background deposits, with thin to thick laminae (Figure 5).

Lithofacies LF1, LF2, and LF5 commonly occur over the entire stratigraphic section, irrespective of the vertical stratigraphic position (Figure 6). Among the mudstonedominated lithofacies, LF3 occurs only in the upper-middle Montney Formation. This lithofacies is indicative of an abundant supply of silt and mud sediment transported from the proximal shoreface. Massive siltstone (LF4) represents the middle to the outer-shelf area. Abundant carbonate minerals and wavy parallel laminae appeared to have formed LF6 and LF8 in the upper Middle Montney Formation. Textural alternations of interbedded, laminated very fine to coarse-grained siltstone (LF6) may have resulted from the intermittent transport of coarse-grained silt within a vertical background setting of fine-grained silt. Occasionally, lithofacies LF8 reaches a thickness of 5-15 cm, with bioclastic event deposits and pyrite. This was likely deposited in an inner shelf to middle shelf environment. Aggregate pyrite and wavy lamination 

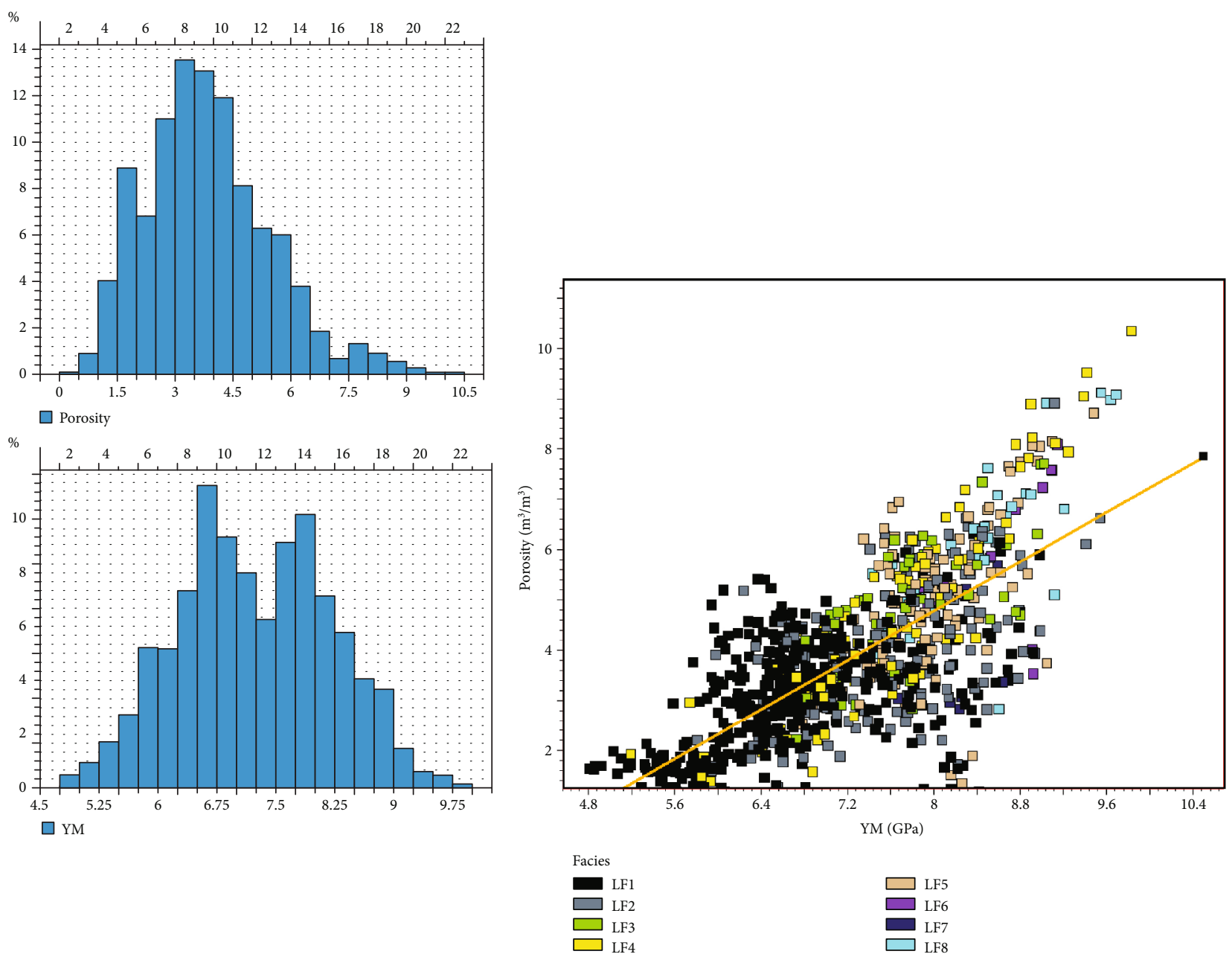

Figure 9: Young's modulus (YM) -porosity plot (right) and histogram range (left).

observed within this lithofacies may have formed during diagenesis [43]. In the upper Montney Formation, lithofacies LF7 contain burrowing and cryptobioturbation, which are linked to the inner-shelf environment (Figure 5). Thorium $(\mathrm{Th}) /$ uranium $(\mathrm{U})$ ratios have been displaying with core lithofacies (Figure 6). This suggests that oxidized continental sediments have higher $(>7) \mathrm{Th} / \mathrm{U}$ ratios than those of the nonoxidized marine sediments $[44,45]$. The entire interval is shown to be below the $\mathrm{Th} / \mathrm{U}$ ratio of 7 .

5.2. Lithofacies and Porosity and Permeability. Porosity and permeability are critical reservoir parameters and reflect depositional and diagenetic processes $[46,47]$. The measured core porosity of 38 samples ranges from 0.012 to 0.07 , averaging 0.04 fraction. Wireline log-derived porosity of the Montney Formation ranges from 0.4 to $10.4 \%$ and shows a wide variation among different lithofacies, which are generally low, averaging $3.84 \%$ with 1.63 of standard deviation (Table 2).

Porosity in the homogeneous mudstone (LF1) is lowest among the lithofacies (3.03\%). LF2, 3, 4, 5, and 7 have greater than $4 \%$ porosity, whereas LF6 and LF8 have higher porosity $(5.78 \%$ and $6.15 \%)$. In the study area, the porosity of individual lithofacies varies with lamination type and occurrence.
The measured core permeability of 38 points ranges from 0.01 to 0.05 , averaging $0.0278 \mathrm{mD}$. There does not seem to be a significant change in permeability with depth, due to the relatively low in the Montney Formation. The mudstonedominated lithofacies LF1, LF2, and LF3 show lower permeability, which might be attributed to their fine texture and increased clay mineral contents. However, permeability slightly increases with the degree of laminae increase (Figure 7(b)). The silt-dominated lithofacies LF4 and LF5 show a slightly higher percentage permeability, and LF7 shows the lowest permeability. Abundant calcite content demonstrates that LF6 and LF8 have the highest permeability, which can be attributed to the well-preserved pore space of the calcite. There is a positive correlation between the degree of lamination and the measured porosity and permeability (Figures 7(a) and 7(b)).

Shale lamination can enhance porosity when there is good sorting because the porosity of shales reflects textural properties, such as grain size distribution, degree of sorting, grain shape, grading, and sediment fabric [48]. Individual laminae are closely linked to specific transport and depositional events such as bottom flow currents, low-density turbidity currents (e.g., LF3 and LF4), suspension settling (e.g., LF1), microbial mat formation (e.g., LF8), and bioturbation 

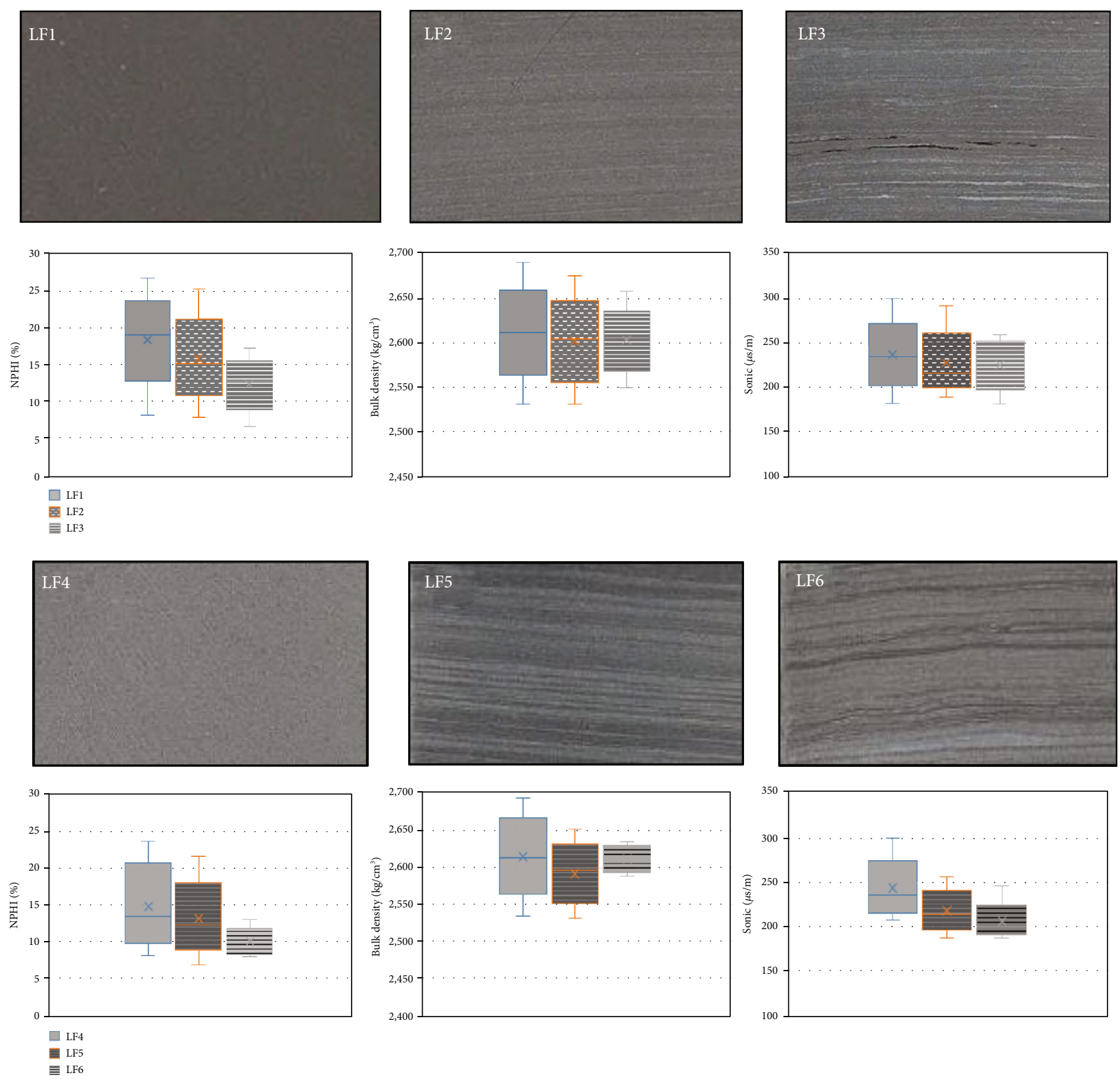

FIGURE 10: Box and whisker plot for LF1-6 in the neutron, density, and sonic logs.

(e.g., LF 7) [13, 49-51]. The porosity values in LF3 and LF6 show a relatively higher average percentage within similar lithology (Figure 7(a); Table 2). The higher values in these lithofacies can be explained in terms of good sorting, thereby leading to a well-developed interangular porosity that is clearly observed in thin sections (Figure 4).

5.3. Lithofacies, Young's Modulus, and Reservoir Quality (RQ). In order to evaluate the prolific reservoir, we designate "reservoir quality." It is estimated from detrital components, total clay, total cement, mechanical properties, calculated porosity, and TOC. We calculated Young's modulus, Poisson's ratio, TOC content, and porosity from wireline logs $[52,53]$. The calculated mechanical properties are compared with detrital components, total clay, and
TOC (Figure 8). There have been reports that brittle shale successions represent high Young's modulus and low Poisson's ratio $[54,55]$. Young's modulus is also used as a function of clay content with TOC $[56,57]$. Increased clay content is related to a decreased Young's modulus and an increased Poisson's ratio. Young's modulus has a positive correlation with laminae facies and porosity $\left(R^{2}=0.78\right)$ (Figure 9) and may represent the elastic anisotropy of shale laminae. The results show that the increase in degree of lamination affects the augmentations in Young's modulus, thereby improving the reservoir quality (Figures 7(c) and 8). Young's modulus decreases as the clay content and TOC increase [57]; however, our results only show clay contents related to Young's modulus in the Montney Formation (Figure 8), because they have relatively low TOC 
contents, averaging $<1 \mathrm{Wt} \%$, with a maximum value of $3.2 \mathrm{Wt} \%$.

However, RQ also depends on the gas in place (interstitial and adsorbed), permeability, organic content, degree of maturation, and pore pressure [58-60]. These features do not have a direct link with texture and sedimentary structures; therefore, the relationship between RQ and laminationbased facies is limited. In this study, Young's modulus shows a strong positive correlation with RQ with $R^{2}$ above 0.9 . As such, lamination-based facies would suggest a key for the correlation.

5.4. Lithofacies and Wireline Log Pattern. There is no universal relationship between wireline log and lamination. This study attempts to reveal the characteristics of the wireline log pattern of potentially prolific core facies through the differentiation of lamination lithofacies from well logs $[36,53]$. The range of neutron logs in lithofacies varies considerably; however, LF1 has an unusually high neutron range compared to those of laminated lithofacies (LF2 and LF3) (Figure 10). The neutron $\log$ is not a well-defined lithofacies and may become diagnostic when combined with sonic and density logs. The shale formation typically shows a higher neutron than other sedimentary rocks. The high neutron content in shale is due to its high clay mineral content (Table 1). Among the siltstone lithofacies, massive siltstone (LF4) has a higher neutron percentage than that of LF5, which could be the result of the higher clay contents (Table 1, Figure 10). The laminated lithofacies has a consistently lower neutron percentage than that of homogeneous facies (Figure 10). Increased siltbearing laminae may affect the lower neutron percentage.

LF1 has a large density differentiation (2530$2690 \mathrm{~kg} / \mathrm{m}^{3}$ ), whereas the density of silt-bearing laminae facies (LF2 and LF3) varies over a relatively narrow range (LF2: $2531-2674 \mathrm{~kg} / \mathrm{m}^{3}$; LF3: $2550-2657 \mathrm{~kg} / \mathrm{m}^{3}$ ). In the case of siltstone, massive siltstone (LF4) shows a higher density value than that of LF5. However, LF7 shows a narrow range and high average density, which may be affected by the high calcite mineral content (32\%).

The sonic log is sensitive to subtle rock texture variations [53]. An increase in the degree of lamination decreases the sonic log response (Figure 10). Although laminae containing lithofacies exhibit good porosity (Figure $7(\mathrm{a})$ ), the effect of lamination facies on increasing or decreasing the porosity is also a problem for log analysts, with the Montney Formation being a good example. We can observe that the degree of lamination has an influence on the neutron, density, and sonic log responses. The neutron log shows the strongest dependency on clay content and on the degree of silt laminae. The density log shows less dependency on clay minerals, and high dependency on cement minerals, for example, detrital quartz and calcite. The sonic log shows the strongest dependency on grain dispersal and grain size; therefore, mineral content is considered as the influence of lamination in the wireline logs.

\section{Conclusion}

We have emphasized lamination in the shale lithofacies classification and shale characterization. Laminated lithofacies were most common in the Montney Formation and are records of different depositional environments and sediment sources. Lamination is related to grain size and various types of mineral components. Increasing silt laminae in mudstone exhibit higher quartz and calcite contents, while comprising lower dolomite and clay mineral contents in the study area.

The degree of lamination with a similar background lithology affects the porosity, permeability, and Young's modulus. A positive correlation of porosity, permeability, and Young's modulus was observed; however, the effect of lamination is not significant or limited on reservoir quality as compared to the effect of lamination on porosity and Young's modulus.

It appears that the degree of lamination affected the neutron, density, and sonic log response. The presence of lamination tends to decrease the neutron percentage, with similar trends in density and sonic log box plots in Montney Formation. The composition, sediment structure, and grain size affect the wireline log response, to reveal the effect of lamination in the wireline log response considered mineral contents. The results of this study could facilitate the classification of shale lithofacies and the interpretation of depositional processes of shale facies, thereby enhancing the usefulness of shale lithofacies analysis in shale reservoir characterization.

\section{Data Availability}

The XRF, wireline logs data used to support the findings of this study are included within the article.

\section{Conflicts of Interest}

The authors declare that they have no conflicts of interest.

\section{Acknowledgments}

The authors would like to thank Dr. O. Ardakani for constructive comments on the early version of the manuscript and thank them for their support with a university software license to Petrel 2018. This research was supported by the Korea Institute of Energy Technology Evaluation and Planning (KETEP) and the Ministry of Trade, Industry \& Energy (MOTIE) of the Republic of Korea (No. 20178510030880) and the Basic Science Research Program through the National Research Foundation of Korea (NRF) funded by the Ministry of Education (No. 2018R1A6A3A01012524).

\section{References}

[1] C. V. Campbell, "LAMINA, laminaset, bed and bedset," Sedimentology, vol. 8, no. 1, pp. 7-26, 1967.

[2] J. Schieber, "The possible role of benthic microbial mats during the formation of carbonaceous shales in shallow midProterozoic basins," Sedimentology, vol. 33, no. 4, pp. 521536, 1986.

[3] A. E. Kemp, "Laminated sediments as palaeo-indicators," Geological Society, London, Special Publications, vol. 116, no. 1, pp. vii-xii, 1996. 
[4] D. S. Ulmer-Scholle, P. A. Scholle, J. Schieber, and R. J. Raine, "A color guide to the petrography of sandstones, siltstones, shales and associated rocks," American Association of Petroleum Geologists, vol. 109, 2014.

[5] J. Schieber, "Deposition of mudstones and shales: overview, problems, and challenges," Shales and mudstones, Volume I, Basin studies, Sedimentology, and Paleontology, pp. 131-146, Schweizerbart'sche Verlagsbuchhandlung, Stuttgart, Germany, 1998.

[6] Z. Yawar and J. Schieber, "On the origin of silt laminae in laminated shales," Sedimentary Geology, vol. 360, pp. 22-34, 2017.

[7] S. Eittreim, M. Ewing, and E. M. Thorndike, "Suspended matter along the continental margin of the North American Basin," Deep Sea Research and Oceanographic Abstracts, vol. 16, no. 6, pp. 613-624, 1969.

[8] E. D. Schneider, P. J. Fox, C. D. Hollister, H. D. Needham, and B. C. Heezen, "Further evidence of contour currents in the western North Atlantic," Earth and Planetary Science Letters, vol. 2, no. 4, pp. 351-359, 1967.

[9] H. Blatt, G. V. Middleton, and R. C. Murray, Origin of Sedimentary Rocks, Englewood Cliffs, New Jersey, Prentice-Hall, 2nd edition, 1980.

[10] A. H. F. Robertson, "Origin of varve-type lamination, graded claystones and limestone-shale 'couplets' in the lower Cretaceous of the western North Atlantic," Geological Society, London, Special Publications, vol. 15, no. 1, pp. 437-452, 1984.

[11] P. E. Potter, J. B. Maynard, and P. J. Depetris, Mud and Mudstones: Introduction and Overview, Springer Science \& Business Media, 2005.

[12] N. R. O'Brien, "Significance of lamination in Toarcian (lower Jurassic) shales from Yorkshire, Great Britain," Sedimentary Geology, vol. 67, no. 1-2, pp. 25-34, 1990.

[13] N. R. O'Brien, "Shale lamination and sedimentary processes," Geological Society, London, Special Publications, vol. 116, no. 1, pp. 23-36, 1996.

[14] F. Ning, X. Wang, X. Hao et al., "Occurrence mechanism of shale oil with differential lithofacies in Jiyang depression," Acta Petrolei Sinica, vol. 38, pp. 185-195, 2017.

[15] Z. Shi, Z. Qiu, D. Dong, B. Lu, P. Liang, and M. Zhang, "Lamina characteristics of gas-bearing shale fine-grained sediment of the Silurian Longmaxi Formation of Well Wuxi 2 in Sichuan Basin, SW China," Petroleum Exploration and Development, vol. 45, no. 2, pp. 358-368, 2018.

[16] Y. Abousleiman, M. Tran, S. Hoang, J. A. Ortega, and F. J. Ulm, "Geomechanics field characterization of Woodford Shale and Barnett Shale with advanced logging tools and nanoindentation on drill cuttings," The Leading Edge, vol. 29, no. 6, pp. 730-736, 2010.

[17] S. Cheng, R. Lan, Z. Jinzhou, T. Xiucheng, and W. Leize, “A comprehensive evaluation index for shale reservoirs and its application: a case study of the Ordovician Wufeng Formation to Silurian Longmaxi Formation in southeastern margin of Sichuan Basin, SW China," Petroleum Exploration and Development, vol. 44, no. 4, pp. 686-695, 2017.

[18] R. M. Slatt and Y. Abousleiman, "Merging sequence stratigraphy and geomechanics for unconventional gas shales," The Leading Edge, vol. 30, no. 3, pp. 274-282, 2011.

[19] R. Sierra, M. H. Tran, Y. N. Abousleiman, and R. M. Slatt, "Woodford shale mechanical properties and the impacts of lithofacies," in 44th US rock mechanics symposium and 5th
US-Canada rock mechanics symposium, Salt Lake City, Utah, 2010.

[20] M. Mokhtari and A. N. Tutuncu, "Impact of laminations and natural fractures on rock failure in Brazilian experiments: a case study on Green River and Niobrara formations," Journal of Natural Gas Science and Engineering, vol. 36, pp. 79-86, 2016.

[21] X. U. Dan, H. U. Ruilin, G. A. O. Wei, and X. Jiaguo, "Effects of laminated structure on hydraulic fracture propagation in shale," Petroleum Exploration and Development, vol. 42, no. 4, pp. 573-579, 2015.

[22] J. Schieber, J. Southard, and K. Thaisen, "Accretion of mudstone beds from migrating floccule ripples," Science, vol. 318, no. 5857, pp. 1760-1763, 2007.

[23] D. E. Edwards, J. E. Barclay, D. W. Gibson, G. Kvill, and E. Halton, "Triassic strata of the Western Canada sedimentary basin," Bulletin of Canadian Petroleum Geology, vol. 38, no. 1, p. $163,1990$.

[24] D. R. Kendall, Sedimentology and Stratigraphy of the Lower Triassic Montney Formation, Peace River Basin, Subsurface of Northwestern Alberta, [M.S. thesis], University of Calgary, 1999.

[25] National Energy Board, "The ultimate potential for unconventional petroleum from the Montney Formation of British Columbia and Alberta," National Energy Board, vol. 17, 2013.

[26] V. Crombez, F. Baudin, S. Rohais et al., "Basin scale distribution of organic matter in marine fine-grained sedimentary rocks: insight from sequence stratigraphy and multi-proxies analysis in the Montney and Doig formations," Marine and Petroleum Geology, vol. 83, pp. 382-401, 2016.

[27] G. R. Davies, T. F. Moslow, and M. D. Sherwin, "The Lower Triassic Montney Formation, west-central Alberta," Bulletin of Canadian Petroleum Geology, vol. 45, pp. 474-505, 1997.

[28] M. L. Golding, M. J. Orchard, J. P. Zonneveld, and N. S. F. Wilson, "An exceptional record of the sedimentology and biostratigraphy of the Montney and Doig formations in British Columbia," Bulletin of Canadian Petroleum Geology, vol. 62, pp. 157-176, 2014.

[29] C. M. Henderson and S. Schoepfer, "High-resolution biostratigraphic and XRF-geochemical correlation of the Montney Formation, NE BC," in GeoConvention 2017 Abstracts in Calgary, Canada, Geological Association of Canada, 2017.

[30] T. F. Moslow and G. R. Davies, "Turbidite reservoir facies in the Lower Triassic Montney Formation, west central Alberta," Bulletin of Canadian Petroleum Geology, vol. 45, pp. 507-536, 1997.

[31] J. P. Zonneveld, R. B. MacNaughton, J. Utting, and C. M. Henderson, "Sedimentology and ichnology of the Lower Triassic Montney Formation in the Pedigree-Ring/Border-Kahntah River area, northwestern Alberta and northeastern British Columbia," Bulletin of Canadian Petroleum Geology, vol. 57, no. 2, pp. 115-140, 2010.

[32] D. W. Gibson and J. E. Barclay, "Middle Absaroka Sequence, the Triassic stable craton," in Western Canada Sedimentary Basin: A Case History, B. D. Ricketts, Ed., pp. 219-231, Canadian Society of Petroleum Geologists, 1989.

[33] D. W. Gibson and D. E. Edwards, "An overview of Triassic stratigraphy and depositional environments in the Rocky Mountain Foothills and Western Interior Plains, Peace River Arch area, northeastern British Columbia," Bulletin of Canadian Petroleum Geology, vol. 38A, pp. 146-158, 1990. 
[34] G. R. Davies, N. Watson, T. F. Moslow, and J. A. MacEachern, "Regional subdivisions, sequences, correlations and facies relationships of the Lower Triassic Montney Formation, west-central Alberta to northeastern British Columbia. Canada-with emphasis on role of paleostructure," Bulletin of Canadian Petroleum Geology, vol. 66, no. 1, pp. 23-92, 2018.

[35] R. H. Bennett, N. R. O'Brien, and M. H. Hulbert, Microstructures of Fine-Grained Sediments, Springer-Verlag, New York, NY, 1991.

[36] O. Serra and L. Serra, Well Logging and Geology, Serralog, 2003.

[37] J. Schieber and J. B. Southard, "Bedload transport of mud by floccule ripples-direct observation of ripple migration processes and their implications," Geology, vol. 37, no. 6, pp. 483-486, 2009.

[38] A. V. Jopling and R. G. Walker, "Morphology and origin of ripple-drift cross-lamination, with examples from the Pleistocene of Massachusetts," Journal of Sedimentary Research, vol. 38, no. 4, pp. 971-984, 1968.

[39] N. R. O'Brien, K. Nakazawa, and S. Tokuhashi, "Use of clay fabric to distinguish turbiditic and hemipelagic siltstones and silts," Sedimentology, vol. 27, no. 1, pp. 47-61, 1980.

[40] S. Boggs Jr. and S. Boggs, Petrology of Sedimentary Rocks, Cambridge university press, 2009.

[41] H. Mansurbeg, M. A. El-ghali, S. Morad, and P. PlinkBjörklund, "The impact of meteoric water on the diagenetic alterations in deep-water, marine siliciclastic turbidites," Journal of Geochemical Exploration, vol. 89, no. 1-3, pp. 254-258, 2006.

[42] T. F. Moslow, B. Haverslew, and C. M. Henderson, "Sedimentary facies, petrology, reservoir characteristics, conodont biostratigraphy and sequence stratigraphic framework of a continuous $(395 \mathrm{~m})$ full diameter core of the Lower Triassic Montney Fm, northeastern British Columbia," Bulletin of Canadian Petroleum Geology, vol. 66, no. 1, pp. 259-287, 2018.

[43] J. D. Hudson, "Pyrite in ammonite-bearing shales from the Jurassic of England and Germany," Sedimentology, vol. 37, pp. 639-667, 1982.

[44] S. Davies and T. Elliott, "Spectral gamma ray characterization of high resolution sequence stratigraphy: examples from Upper Carboniferous fluvio-deltaic systems, County Clare, Ireland," Geological Society, London, Special Publications, vol. 104, no. 1, pp. 25-35, 1996.

[45] L. Chen, Y. Lu, S. Jiang et al., "Sequence stratigraphy and its application in marine shale gas exploration: a case study of the Lower Silurian Longmaxi Formation in the Jiaoshiba shale gas field and its adjacent area in outheast Sichuan Basin, SW China," Journal of Natural Gas Science and Engineering, vol. 27, pp. 410-423, 2015.

[46] J. Goral, P. Panja, M. Deo et al., "Confinement effect on porosity and permeability of shales," Scientific Reports, vol. 10, no. 1, article 49, 2020.

[47] J. Schieber, "Common themes in the formation and preservation of intrinsic porosity in shales and mudstones - illustrated with examples across the Phanerozoic," in SPE Unconventional Gas Conference, Pittsburgh, Pennsylvania, 2010.

[48] D. A. Stow, Sedimentary Rocks in the Field: A Color Guide, Gulf Professional Publishing, 2005.

[49] N. R. O'Brien, "The effects of bioturbation on the fabric of shale," SEPM Journal of Sedimentary Research, vol. 57, no. 3, pp. 449-455, 1987.
[50] N. R. O'Brien, C. E. Brett, and M. J. Woodard, "Shale fabric as a clue to sedimentary processes: example from the WilliamsonWillowvale shales (Silurian), New York," Shales and Mudstones (Volume II, Petrography, Petrophysics, Geochemistry, and Economic Geology), pp. 55-66, Schweizerbart'sche Verlagsbuchhandlung, Stuttgart, Germany, 1998.

[51] N. R. O'Brien and S. Pietraszek-Mattner, "Origin of the fabric of laminated fine-grained glaciolacustrine deposits," Journal of Sedimentary Research, vol. 68, no. 5, pp. 832-840, 1998.

[52] R. D. S. Helix, "Reservoir geomechanics for petrophysicsts," in SPWLA 49th annual symposium, 2008.

[53] M. Rider and M. Kennedy, The Geological Interpretation of Well Logs, Rider-French Consulting Ltd, 2011.

[54] W. V. Grieser and J. M. Bray, "Identification of production potential in unconventional reservoirs," in Production and Operations Symposium, Society of Petroleum Engineers, 2007.

[55] G. E. King, "60 years of multi-fractured vertical, deviated and horizontal wells: what have we learned?," in Paper SPE 17095 presented at the SPE Annual Technical Conference and Exhibition, Amsterdam, The Netherlands, 2014.

[56] H. Sone and M. D. Zoback, "Mechanical properties of shalegas reservoir rocks - part 1: static and dynamic elastic properties and anisotropy," Geophysics, vol. 78, no. 5, pp. D381D392, 2013.

[57] M. D. Zoback and A. H. Kohli, Unconventional Reservoir Geomechanics, Cambridge University Press, 2019.

[58] C. R. Clarkson, N. Solano, R. M. Bustin et al., "Pore structure characterization of North American shale gas reservoirs using USANS/SANS, gas adsorption, and mercury intrusion," Fuel, vol. 103, pp. 606-616, 2013.

[59] C. R. Clarkson, B. Haghshenas, A. Ghanizadeh et al., "Nanopores to megafractures: current challenges and methods for shale gas reservoir and hydraulic fracture characterization," Journal of Natural Gas Science and Engineering, vol. 31, pp. 612-657, 2016.

[60] A. Ghanizadeh, C. R. Clarkson, S. Aquino, O. H. Ardakani, and H. Sanei, "Petrophysical and geomechanical characteristics of Canadian tight oil and liquid-rich gas reservoirs: I. Pore network and permeability characterization," Fuel, vol. 153, pp. 664-681, 2015. 